Insect Sci. Applic. Vol. 17, No. 1, pp. 169-173, 1997

\title{
The Potential Use of Pheromones for the Management of the Millet Stemborer, CONIESTA IGNEFUSALIS (HAMPSON)
}

\author{
Ousmane Youm ${ }^{1}$, Peter S. Beevor ${ }^{2}$, David R. Hall ${ }^{3}$ and Lawrence J. McVeigh ${ }^{3}$ \\ ${ }^{1}$ International Crops Research Institute for the Semi-Arid Tropics, Sahelian Centre, \\ B.P. 12404 Niamey, Niger; \\ 23, Skewbridge Close, Wootton Basset, Wiltshire, SN4 7DW, England; \\ ${ }^{3}$ Natural Resources Institute, Central Avenue, Chatham Maritime, Chatham, \\ Kent ME4 4TB England
}

(Accepted 2 October 1997)

\begin{abstract}
Recent studies on the identification and evaluation of the millet stemborer Coniesta ignefusalis female sex pheromone have shown that pheromone technology is promising as a management component. A review of rescarch shows that an effective pheromone trap has been developed and successfully tested in eight countries in West Africa, through the West and Central African Millet Research Network (WCAMRN/ ROCAFREMI). A regional wide-scale stemborer monitoring network has been developed and is being implemented. Studies on mass trapping and mating disruption indicate that the two techniques have much potential in C. ignefusalis management. Prospects for the implementation of pheromone technology to manage $C$. ignefusalis in the context of an IPM scheme are discussed.
\end{abstract}

Key Words: millet stemborer, Conicsta igncfusalis, pheromone, integrated pest management, Pennisctum glaucum

Résumé-Des études récentes sur l'identification et l'évaluation de la phéromone sexuelle de la femelle du foreur de tiges de mil, Coniesta ignefusalis, ont démontré que la technologie de gestion du foreur basée sur les phéromones était prometteuses. Une revue de la recherche dans le domaine indique qu'un piège à phéromone fiable a été mis au point et testé dans huit pays de l'Afrique de l'Ouest, à travers le Réseau Ouest et Centre Africain pour la Recherche sur le Mil (ROCAFREMI). Une surveillance régionale à grande échelle a été entreprise et mise en application. Les résultats des tests sur le piègeage en masse et la confusion sexuelle démontrent que ces deux techniques sont prometteuse dans la lutte contre $C$. ignefusalis. Les perspectives d'application de la technologie basée sur la phéromone dans la gestion de $C$. igncfusalis dans un contexte schématique de lutte intégrée ont fait l'objet de discussion.

Mots Clés: foreurs de tiges de mil, Coniesta ignefusalis, phéromone, lutte intégrée, Pcnnisetum glaucum

\section{INTRODUCTION}

earl millet is the major staple food crop in Sahelian West Africa. The millet stemborer, Coniesta ignefusalis (Hampson)(Lepidoptera: Pyralidae) is well known as a persistent and key pest of pearl millet, Pennisetum glaucum (L.) R. Corresponding author: OY.
Brown, (Youm et al., 1996, Youm and Gilstrap, 1993; Harris, 1962). It is not known to be a major pest of other cereals, and its importance as a pest of pearl millet extends in the West African Sahelian and Sudano-Sahelian zones (Harris, 1962; N'doye and Gahukar, 1987; Youm, 1990). Damage and crop losses caused by $C$. ignefusalis are primarily due to feeding by larvae developing inside the 
stems. Coniesta ignefusalis damage is often more important near fences and around granaries made of millet stems (Harris, 1962; Youm et al., 1996). Crop losses are variable across regions and between years, but severe attack can result in losses ranging from $15 \%$ up to total crop failure (Harris, 1962; Ajayi, 1990).

Integrated management options for the millet stemborer are addressed in a recent review by Youm et al. (1996). Among integrated pest management (IPM) strategies, cultural control and the use of pheromones are promising techniques for the management of $C$. ignefusalis. Numerous indigenous biological control agents have been identified, but they do not provide effective control of the millet stemborer (Youm, 1990; Youm and Gilstrap, 1993), suggesting the need to search for more efficient natural enemies. Host plant resistance through non-preference for oviposition has potential: the presence of leaf trichomes is associated with reduced borer oviposition (Youm, unpublished).

Development of IPM of any insect requires the understanding of the insect's bioecology as well as the socioeconomic factors which would encourage or limit its implementation.

Since the borer remains in diapause in dry, harvested millet stems during the dry season (Harris, 1962; Youm et al., 1996), the residual population at the end of the dry season is a primary source of infestation for the new millet crop during the following rainy season. Crop residue management techniques provide an effective method for reducing the population density and the damage caused by $C$. ignefusalis on pearl millet (YoumandGilstrap, 1994; Youmetal., 1996).Cutting stems and laying them on the soil surface soon after harvestorburyingstems $5 \mathrm{~cm}$ below the soil surface provides more than $90 \%$ control of carry-over populations (Lukefahr et al., 1988; Youm et al., 1993a). In Burkina Faso, Bouchard et al. (1993) reported thatharvestingmilletstemsinearly tolate November resulted in a $76-92 \%$ reduction in carryover of diapausing populations of $C$. ignefusalis compared to harvesting them in December.

Apart from the use of pearl millet as a food grain, millet stems are used for roofing, fencing, building traditional granaries, construction of rural schools, shop kiosks, and animal bedding (Harris, 1962; Youm et al., 1996). It is therefore evident that crop residues management as the sole control measure would be difficult to implement, and any wide-scale implementation of IPM strategies to control the millet stemborer would require taking into account the socioeconomic environment and the farmer's needs.

Add-on strategies such as pheromone technology can be integrated as potential key components of an overall management strategy. This paper documents the development, as well as the prospects for implementation of pheromone technology as a management component for $C$. ignefusalis. It also outlines and discusses the key elements for its effective IPM implementation and research perspectives.

\section{DEVELOPMENT AND IMPLEMENTATION of Pheromone Technology}

\section{Identification and field evaluation of the female sex pheromone}

Production of a female sex pheromone by $C$. igncfusalis was demonstrated during studies to develop control strategies (Bako, 1977; ICRISAT, 1989). A collaborative research project between ICRISAT and the Natural Resources Institute (NRI) has subsequently resulted in the identification, synthesis, and field evaluation of the pheromone blend (Youm et al., 1993b). Attractive components of the female sex pheromone are combined in an optimum pheromone blend comprised of (Z)-7-dodecen-1ol $(\mathrm{Z7}-12: \mathrm{OH})(500 \mu \mathrm{g})+(\mathrm{Z})$-5-decen-1-ol (Z5$10: \mathrm{OH})(25 \mu \mathrm{g})+(\mathrm{Z})-7$-dodecenal $(\mathrm{Z7}-12: \mathrm{CHO})$ $(16.67 \mu \mathrm{g})$ (Youm et al., 1993b). Field evaluation showed that the synthesised pheromone attracted more male moths than did virgin females (Beevor et al., unpublished data, cited in Youm et al., 1993b). Although the pheromone blend was effective in attracting males, the development of a trap design adapted to Sahelian conditions was required.

Development and field evaluation of pheromone-baited traps

Research on design and field evaluation of pheromone traps baited with the synthesised female sex pheromone of $C$. igncfusalis showed that a sticky board trap was relatively ineffective, whereas a water-oil pheromone trap showed good promise (Youm et al., 1993b). This latter locally made trap was further developed and optimised (Youm and Beevor, 1995). Catches of male C. ignefusalis moths were significantly affected by trap tray sizes, with a $32-\mathrm{cm}$ diameter size being 
more effective and easier to handle than smaller or larger ones. Optimum trap shade size was 8$21 \mathrm{~cm}$ and, optimum trap shade height was 2-5 $\mathrm{cm}$. Motor oil, soap, and liquid detergents were more effective as surfactants than vegetable oil (Youm and Beevor, 1995). Optimum trap height was $0.5 \mathrm{~m}$. Trap trays made of aluminum or a more durable material were recommended due to the harsh and hot climatic conditions typical of Sahelian millet growing areas. An effective low-cost pheromone trap, with a long-lasting polythene pheromone dispenser, has been recommended for use in monitoring stemborer populations by farmers, and also national and international agricultural research stations (NARS and IARS)s and organisations in Sahelian West Africa (Youm and Beevor, 1995).

\section{Population monitoring}

Pheromone trapping systems are relevant tools in population monitoring of crop pests (Nesbitt, 1978) and can provide a means for sensitive and specific monitoring of adult moth populations even at low densities (e.g. Wall, 1989; Srivastava and Srivastava, 1989). They are effective and offer alternatives to light traps for the timing of control measures (Campion et al., 1976) and are practical for use in developing countries due to their low cost and species specificity (Campion et al., 1987; Youm et al., this volume).

Youm et al. (in press) reported a good correlation between catches in pheromone and light traps in Niger during the millet growing season from mid-June to the first week of October. Pheromone trap efficiency at very low moth population levels was reported and supports the use of pheromone traps to detect early infestation (Campion and Nesbitt, 1981). Because of their ease of usage and low cost, and the possibility for using pheromone traps even at remote village farms with no artificial light sources the water-oil trap baited with the optimum blend of C. ignefusalis pheromone is recommended for use both onstation and on-farm for monitoring stemborer populations. The trap baited with the synthetic optimum blend of the female pheromone was successfully tested in Benin, Burkina Faso, Gambia, Ghana, Mali, Niger, Nigeria and Senegal, through the West and Central African Millet Research Network (WCAMRN/ROCAFREMI) (ICRISAT, 1994, 1996; Youm et al., 1995). Catches across these countries using the same pheromone blend and traps showed that there are no separate geographic races of the millet stemborer which would require the development of different pheromone blends.This regional stemborer monitoring network is being strengthened through WCAMRN/ROCAFREMI.

\section{Mass trapping and mating disruption}

Studies on mass trapping as a component of $C$. ignefusalis management have been initiated to assess its effectiveness in reducing the incidence of the millet stemborer(Youm, 1996). The technique was tested on-farm, using water-oil-based traps baited with $C$. ignefusalis pheromone blend. Traps were placed around farmers' granaries, a major source of stemborer carry-over. At $25 \mathrm{~m}$ radius from granaries, damage in terms of percent infested hills and percent deadhearts (per 100- $\mathrm{m}^{2}$ sample plot) was lower in treated plots than in control plots. At a distance of $50 \mathrm{~m}$ from granaries, damage levels were higher in control than in treated plots (Youm, 1996). At $100 \mathrm{~m}$ distance from granaries control was less effective with increased trap spacing and reduced trap density. Studies of placing traps around sources of infestation such as crop residues, fences, granaries to reduce population carry-over are in progress and should help determine the efficiency of mass trapping for the control of the millet stemborer. Implication in terms of socioeconomic benefits to smallscale farmers will be assessed before recommending wider use of the technology. Further evaluation of the mass trapping technique will continue and cost/benefit analysis will be conducted to determine long-term benefits for adoption and sustainability.

Mating disruption was assessed near the ICRISAT Sahelian Center at Sadore in 1993 (ICRISAT, 1994, 1995). Effective disruption of communication was demonstrated by a reduction in pheromone-trap catches of male moths in plots treated with pheromone dispensers compared with catches in untreated plots. Two pheromone 'inhibitors', (Z)-9-tetradecen-1-ol and (Z)-7dodecenyl acetate (known to reduce catches of male moths when added to the attractive pheromone blend in traps), were less effective in disrupting communication. The dispensers used in 1993 lasted only one week in the field, needing weekly replacement. Longer-lasting formulations need to be developed to reduce the time and cost of field implementation of the technique. Polythene 
dispensers loaded with the synthesised optimum pheromone blend (lasting 4-6 weeks) are being currently used to assess the technique further.

\section{Perspectives on IPM}

\section{IMPLEMENTATION FOR $C$. IGNEFUSALIS}

\section{Management}

A review of current and past research on the millet stemborer management has shown that much has been achieved during the past 45 years (Youm et al., 1996). The use of tolerant varieties, cultural control practices such as crop residues management, biological control and the use of synthesised female sex pheromones could provide effective control of stemborer. Areas for further research and training in the use of pheromones for C. ignefusalis management should include the following: (a) train NARS on the use of pheromone technology and its application in crop protection, including handbooks and brochures; (b) re-assess the role of two 'inhibitor components' contained in female stemborer sex pheromone; (c) develop longer-lasting dispensers for use in mating disruption; (d) assess socioeconomic benefits for using mass-trapping and mating disruption to control stemborer; (e) strengthen the regional monitoring network; (f) develop a model for predicting stemborer outbreaks based on population carry-over and monitoring using pheromone traps; $(g)$ use and evaluate the pheromone technology in farmer-participatory training approaches; and (h) study constraints to farmer adoption of pheromone technology and other IPM components to manage the millet stemborer

Acknowledgments-This paper was approved as an ICRISAT CP \#1098. NRI's inputs to this work were funded by the UK Department For International Development (DFID) for the benefit of developing countries. The views expressed are not necessarily those of DFID [R5281, Crop Protection Programme].

\section{REFERENCES}

Ajayi O. (1990) Possibilities for the integrated control of the millet stem borer, Acigona ignefusalis Hampson (Lepidoptera: Pyralidae), in Nigeria. Insect Sci. Applic. 11, 109-117.

Bako O. (1977) Etude biologique de Haimbachia ignefusalis (Hamps.) (Lepidoptera: Pyralidae,
Crambinae)en vue d'une lutte biologique. These de Maitrise. Université Laval, Quebec, Canada.

Bouchard D., Ouedraogo A. and Boivin G. (1993) Impact de la coupe des tiges sur les larves diapausantes de Coniesta (- Acigona) igncfusalis (Lepidoptera: Pyralidae). Insect Sci. Applic. 14, 31-37.

Campion D. G., Hall D. R. and Prevett P. F. (1987) Use of pheromones in crop and stored products pest management: Control and monitoring. Insect Sci. Applic. 8, 737-741.

Campion D. G. and Nesbitt B. F. (1981) Lepidopteran sex pheromones and pest management in developing countries. Trop. Pest Manage. 27, 53-61.

Campion D. C., Odiyo P. O., Mushi A. M., Hall D. R., Lester R. and Nesbitt B. F. (1976) Field tests with the synthetic sex pheromone of the African army worm. Miscellaneous report No. 25. Ministry of Overseas Development. Centre for Overseas Pest Research, College House Wrights Lane. London W8 5SJ, UK.

Harris K. M. (1962) Lepidopterous stemborers of cereals in Nigeria. Bull. Entomol. Res. 53, 139-171.

ICRISAT (International Crops Research Institute for the Semi-A rid Tropics) (1989)ICRISAT West African Programs: Annual Report 1988. ICRISAT Sahelian Centre, Niamey, Niger.

ICRISAT (International Crops Research Institute for the Semi-Arid Tropics)(1994)ICRISAT Now: Sowing for the Future. A.P. 502 324, ICRISAT, India.

ICRISAT (International Crops Research Institute for the Semi-Arid Tropics) (1995) ICRISAT Report 1994. A.P. 502324, ICRISAT, India.

ICRISAT (International Crops Research Institute for the Semi-Arid Tropics) (1996) ICRISAT and Collaborative Programs, West and Central Africa Region: Annual Report 1994. ICRISAT Sahelian Centre, Niamey, Niger.

Lukefahr M. J., Mamalo A. K. and Klaij M. C. (1988) Survival of the millet stem borer, Conicsta (Acigona) igncfusalis during the non growing season, pp. 3134. In Proceedings of Regional Millet Workshop IARABU/ICRISAT, Zaria, Nigeria, 15-19 Aug 1988. International Crops Research Institute for the SemiArid Tropics (ICRISAT) Sahelian Centre, Niamey, Niger.

N'doye M. and Gahukar R. T. (1987) Insect pests of pearl millet in West Africa and their control, pp. 195-205. In Proceedings of the International Pearl Millet Workshop, 7-11 April 1986. ICRISAT Centre, Patancheru, A. P. 502 324, India.

Nesbitt B. F. (1978) A review of work on insect pheromones at the Tropical Products Institute. Trop. Sci. 20, 1-10.

Srivastava C. P. and Srivastava R. P. (1989) Comparison of Heliothis armigera (Hübner) male moth catches in light and pheromone traps at Udaipur, Rajasthan, India. Insect Sci. Applic. 10, 565-568.

Wall C. (1989) Monitoring and spray timing, pp. 39-66. In Insect Pheromones in Plant Protection (Edited by A. R. Jutsum and R. F.S. Gordon). John Wiley and Sons Ltd, Chichester. 
Youm O. (1990) Evaluation of natural enemies associated with the millet stalk borer, Haimbachia igncfusalis (Hampson) (Lepidoptera: Pyralidae) in Niger. Ph.D dissertation. Texas A\&M University, CollegeStation, Texas, USA.

Youm O. (1996) Integrated management of pearl millet insect pests. ICRISAT and Collaborative Programs, West and Central Africa Region: Annual report 1994. ICRISAT Sahelian Centre, Niamey, Niger.

Youm O. and Beevor P. S. (1995) Field evaluation of pheromone-baited traps for Coniesta ignefusalis (Lepidoptera: Pyralidae) in Niger. I. Econ. Entomol. 88, 65-69.

Youm O., Mamalo A. K., Nwanze K. F. (1993a) Bioecology and integrated management of the millet stem borer (Lepidoptera: Pyralidae): A review and current research at the ICRISAT Sahelian Centre, pp. 55-63. In Proceedings of the Regional Pcarl Millet Workshop, 19-21 September, 1990, ICRISAT Sahelian Centre, B.P. 12404, Niamey, Niger. Pearl Millet Improvement Program (Edited by O. Youm and $\mathrm{K}$. A. Kumar). ICRISAT Sahelian Centre. International Crops Research Institute for the Semi-Arid Tropics. pp. (Scmi-formal publication).

ou., O., Beevor I'. S, and Hall D. R. (1993b) Trap design studies with the pheromone of Conicsta igncfusalis (Hampson) (Lepidoptera: Pyralidae) in
sub-Saharan Africa. $1 O B C$ Western Palacarctic Regional Section Bulletin: 16, 58-63.

Youm O., Beevor P.S., McVeigh L. J. and Diop A. (1997) Effect of trap height and spacing in relation to crop height on catches of Conirsta igntfusalis males. Inscit Sci. Applic. 17 (in press).

Youm O. and Gilstrap F. E. (1993) Population dynamics and parasitism of Coniesta ( - Haimbachin) ignefusalis, Sesamin calamistis, and Heliocheilus albipunctella in millet monoculture. Insect Sci. Applic. 14, 419-426.

Youm O. and Cilstrap F. E. (1994) Habitat site selection, crop damage, and oviposition preference by Comiesta (- Haimbachia) igncfusalis (Lepidoptera: Pyralidae). Int. J. Pest Manage. 40, 231-236.

Youm O., Harris K. M. and Nwanze K. F. (1996) Coniesta ignefusalis (Hampson), the millet stem borer: A handbook of infornation. (In En. Summaries in En, Fr, Es.) Information Bullctin, no. 46. International Crops Research Institute for the Semi-Arid Tropics, Patancheru 502 324, Andhra I'radesh, India. $60 \mathrm{pp}$. [Part1: Review pp. 1-18; lart 2: Annotated bibliography $p p$. 19-52] ISBN 92-90)66-253-0.

Youm O., McVeigh L. J., Toure K. and Mahamadou C. I. (1995) Regional monitoring of Comir'stn ignefusalis (Hampson) using pheronone traps: Partial results obtained in Niger and Mali in 1993 and 1994. Quarterly Bullelin: West and Central African Millet Research Netuork (WCAMRN/ROCAFREMI). 7, 1213. 